Agro-Science Journal of Tropical Agriculture, Food, Environment and Extension Volume 17 Number 3 (September 2018) pp. 12-18

ISSN 1119-7455

\title{
THE PHYTOCHEMICAL AND ANTI-MICROBIAL POTENTIAL OF THE EXTRACTS FROM THE FRUIT PULP OF Landlphia owariensis
}

\author{
"Iombor T.T. and Gbeyonron F.M.
}

\author{
Department of Home Science \& Management, University of Agriculture, Makurdi, Nigeria \\ *Corresponding author's email: theophilus0707@gmail.com
}

\begin{abstract}
The phytochemical composition and antimicrobial potential of extracts of fruit pulp of Landolphia owariensis was investigated. L. owariensis mesocarp flour was obtained by oven drying at $50^{\circ} \mathrm{C}$ and pulverized while microwave assisted extraction was used to obtain hexane, chloroform, ethyl acetate and methanol extracts, which were concentrated in vacuo using microwave and thereafter air dried at ambient temperature. Antimicrobial sensitivity tests on fourteen (14) human pathogenic microorganisms were performed using diffusion method while minimum inhibitory concentration (MIC) and minimum bacterial/fungal concentration (MBC/MFC) tests were performed using dilution method. The oven dried L. owariensis fruit pulp flour contained $12.45 \pm 0.03 \mathrm{mg} / 100 \mathrm{~g}$ tannins and $6.39 \pm 2.78 \mathrm{mg} / 100 \mathrm{~g}$ total flavonoids but low levels of anthraquinones, alkaloids, cyanogenic glycosides, saponins, steroids and terpenes. The phytosterols consisted of cholesterol, cholestanol, campesterol, stigmasterol, beta sitosterol and tocopherol with stigmasterol being the most abundant $(1.06 \pm 0.21 \mathrm{mg} / 100 \mathrm{~g})$. The flavonoids constituents included orientin, isovitexin and keampferol. Microbiological analysis of hexane, chloroform, ethyl acetate and methanol extracts of $L$. owariensis fruit pulp showed antimicrobial activities against S. aureus, S. pyogenes, S. typhi, S. dysenteriae, K.pneumoniea, C. albicans, C. krusei, C. stellatoidea and M. rubrum. Chloroform extract exhibited the highest zones of inhibition, followed by hexane and ethyl acetate extracts while methanol extract had least diameter of zones of inhibition. Also ethyl acetate extract was more potent $(2.5-5 \mathrm{mg} / \mathrm{mL})$, followed by chloroform and methanol extracts while hexane extract had the least potency $(5-10 \mathrm{mg} / \mathrm{mL})$ level. Similarly, ethyl acetate extract was most effective $(5-10 \mathrm{mg} / \mathrm{mL})$ in inhibiting bacterial/fungal growth. L. owariensis fruit pulp flour and extracts contained important secondary metabolites that may account for its antimicrobial activities.
\end{abstract}

Key words: Landolphia owariensis, phytochemicals, anti-microbial activities, flavonoids, phytosterols

\section{INTRODUCTION}

In many tropical countries in Africa, rural people traditionally harvest wide range of fruits from the wild because of its taste, cultural uses and as food supplements. Labeled as famine or hunger food, wild plants have been recognized to have potential to meet household food and income security (Guinand and Dechassa, 2000; Kebu and Fassil, 2006). In rural communities of many developing nations, wild fruits are often consumed to complement cultivated commercial fruits. In Nigeria, the indigenous fruits collected from wild play significant role in the food and medicinal needs of rural poor. Scrutiny of plants of various tropical forest areas through constituent analysis may lead to selection of valuable wild species that can be taken through crop improvement and hybridization process to establish it as cultivated variety. Report has it that less than 10 plant species are meeting over $90 \%$ of the world food demand (Wilkes, 1981), however, there is huge diversity of wild plant species whose food and health potentials are underexploited and underutilized. The rural poor in developing nations use wild edible plant species to complement their food and economic resource base. The high rate of deforestation occasioned by urbanization and industrialization is a huge threat to the survival and sustained availability of these wild edible plant species in the nearest future for man's use. Therefore, conscious effort at conserving the economically important wild edible plant species before they really become extinct is required.

Landolphia owariensis P. Beauvis fruit (white rubber vine) is an under-utilized and underexploited wild food plant. Its sweet and sour stringy fruit pulp with numerous seeds are consumed in Southern and North-Central regions of Nigeria; where it is known variously as Nwalika or Eso (Igbo), mba (Yoruba), Ciwo (Hausa), Ana (Idoma) and Ipungwa (Tiv) (Nwaogu et al., 2008; 
Nwaogu et al., 2007). Oil of edible quality has been extracted from its seeds (Akubugwo and Ogbogu, 2007). The hexane, chloroform, ethyl acetate and methanol extracts of Landolphia owariensis fruit back had been reported to contain alkaloids, cardiac glycosides, saponins and terpenes (Iombor and Anyam, 2015). However, not much is known about the phytochemical composition and antimicrobial activity of the fruit pulp extracts. The study therefore, determined the phytochemical composition of $L$. owariensis fruit pulp and elucidated the health potentials of its extracts.

\section{MATERIALS AND METHODS}

Fruits Collection and Drying

Fresh fruits of Landolphia owariensis were collected from the wild forests around Adikpo, Benue State, Nigeria (6 $6^{\circ} 50^{\prime} 37.8$ "N $9^{\circ} 15$ '31.1" E). The plant was identified in the Department of Forest Products and Production, University of Agriculture, Makurdi, Nigeria. The mesocarp (pulp) together with the seeds were extracted after the fresh fruits were split open using a stainless kitchen knife; oven dried at $50^{\circ} \mathrm{C}$ to constant weight, followed by seed removal and pulverization of oven dried pulp using a domestic kitchen blender (Supper master, China). The pulverized pulp was stored in black polyethylene bags in vacuumed desiccators at ambient temperature $\left(36 \pm 1^{0} \mathrm{C}\right)$ until needed for use.

\section{Extraction of Fruit Pulp Material}

Microwave Assisted Extraction was carried out using a domestic microwave oven according to method described by (Abuin et al., 2000) with modifications. The pulverized pulp (100 g) was introduced to extraction vessel [Winchester bottle $(2.5 \mathrm{~L})]$. Two hundred milliliters each of hexane, chloroform, ethyl acetate and methanol were separately added (a solvent at a time, in the sequence listed) to the pulverized pulp and the mixture bombarded with microwaves (70 Watts/Defrost Function) using a domestic kitchen microwave (Mio-star, Model 7173.295, Germany) for 30 minutes (3 minute microwaving with 15 minute cooling pauses). Pressure build up was vented after every two successive sessions by very slowly unscrewing cap of extraction vessel and agitating very gently. Watman number 1 (size: 24 ) filter paper was used to filter the extracts which were then concentrated in vacuo at $40^{\circ} \mathrm{C}$ and air dried at ambient temperature $\left(36 \pm 1{ }^{0} \mathrm{C}\right)$. The dried extracts were stored in clean glass bottles at ambient temperature until required for use.

\section{Quantification of Phytochemical Constituents}

The method of Luthria et al. (1997) was used in quantifying the phytochemical constituents in methanol extract of oven dried fruit pulp of $L$. owariensis, with the aid of gas chromatography- mass spectrometry (GC-MS) (model 6890 gas chromatograph and model 5973 quadrupole mass spectrometer; Hewlett-Packard, Palo Alto, CA). Separations of the individual flavonoids and phytosterols were performed using a DB5 capillary GC column $(30 \times 0.25 \mathrm{~mm}$ internal diameter, 0.25 $\mu \mathrm{m}$ film; J \& W Scientific, Folsom, CA). Splitless injections of $2 \mu \mathrm{L}$ were made and the column temperature was programmed from 150 (held for 3 $\min$ ) to $230^{\circ} \mathrm{C}$ at $5^{\circ} \mathrm{C} / \mathrm{min}$ with a final hold at $230^{\circ} \mathrm{C}$ for $30 \mathrm{~min}$. Helium was used as the carrier gas with a flow rate of $0.7 \mathrm{~mL} / \mathrm{min}$ and with an average linear velocity of $23 \mathrm{~cm} / \mathrm{min}$. Quantitative analysis was performed using 70-eV electron ionization and select-ion monitoring of fragment ions at a mass-to-charge ratio $(\mathrm{m} / \mathrm{z})$ of 355 with a dwell time of $100 \mathrm{~m} / \mathrm{s}$ channel.

\section{Antimicrobial Activities \\ Collection of microbial isolates}

The human pathogens; Staphylococcus aureus; Streptococcus pyogens, Escherichia coli, Salmonella typhi, Shigella dysenteriae, Pseudomonas aeruginosa, Klebsiella pneumonia (bacteria species), Candida albicans, Candida tropicalis, Candida krusei, Candida stellatoidea, Microsporum gypseum, Microsporum spp and Trichophyton rubrum (fungi species) used in the study were obtained from the stock culture of the Department of Medical Microbiology, Ahmadu Bello University Teaching Hospital, Zaria, Kaduna State, Nigeria.

\section{Antimicrobial Sensitivity Test}

The sensitivity of test organisms to n-Hexane, Chloroform, Ethyl acetate and Methanol extracts of Landolphia owerensis fruit mesocarp was carried out using the diffusion method described by Ebi and Ofoefule (1997). The extract $(0.3 \mathrm{~g})$ was weighed and dissolved in dimethyl sulfoxide (DMSO) $(10 \mathrm{~mL})$ to obtain a concentration of 30 $\mathrm{mg} / \mathrm{mL}$. Mueller Hinton agar was used as growth medium for bacteria while Sabouraud dextrose agar was used as growth medium for fungi. The media were prepared according to standard procedures and poured into sterile petri dishes, cooled and allowed to solidify. Sterilized media were fed with standard inocula $(0.1 \mathrm{~mL})$ of test microbes. Inocula were spread evenly over surface of media by use of a sterile swab. Using a standard cork bearer of 6 $\mathrm{mm}$ in diameter, a well was cut at the center of each inoculated medium. The standard solution of the extract $(0.1 \mathrm{~mL})$ of concentration $20 \mathrm{mg} / \mathrm{mL}$ was then introduced into each well on the inoculated medium. The Petri-dishes were allowed to stand for about 30 minutes at room temperature to allow for proper diffusion of extracts to take place. The plates were then incubated at $37{ }^{\circ} \mathrm{C}$ for 24 hours for the bacteria and at $30{ }^{\circ} \mathrm{C}$ for $1-7$ days 
for the fungi. The zones of inhibition of growth in millimetres were measured and recorded.

\section{Minimum Inhibitory Concentration (MIC) Test} The broth dilution method described by (Forbes $e t$ al., 2007) was used to determine the minimum inhibitory concentration. Muller Hinton and Sabouraud dextrose broth were prepared; $10 \mathrm{~mL}$ of the broth was dispensed into test tubes and were sterilized at $121^{\circ} \mathrm{C}$ for 15 minutes and allowed to cool. McFarland turbidity standard scale number 0.5 was prepared to give turbid solution. Normal saline $(10 \mathrm{~mL})$ was prepared and dispensed into sterile test tubes; test microbes were inoculated and incubated at $37{ }^{0} \mathrm{C}$ for 6 hours. Dilution of test microbes in normal saline was made until turbidity reached the Mcfarland scale by visual comparison; at this point test microbes had a concentration of about $1.5 \times 10^{8} \mathrm{cpu} / \mathrm{mL}$. Two-fold dilution of the extract in sterile broth was made to obtain the concentrations of $20,10,5,2.5$ and $1.25 \mathrm{mg} / \mathrm{mL}$. The initial concentration was obtained by dissolving of the extract $(0.3 \mathrm{~g})$ in the sterile broth $(10 \mathrm{~mL})$. Standard inocula of test microbes in normal saline $(0.1 \mathrm{~mL})$ were then inoculated into the different concentrations, onto Mueller Hinton and Sabouraud dextrose broth, incubated at $37{ }^{0} \mathrm{C}$ for 24 hours and $30{ }^{\circ} \mathrm{C}$ for $1-7$ days for bacteria and fungi respectively. Thereafter, each test tube of broth was observed for turbidity (growth). The lowest concentration of extract in broth which showed no turbidity was recorded as minimum inhibition concentration.

\section{Minimum Bacteria/Fungi Concentration (MBC/MFC) test}

Minimum bacteria and fungi concentrations were carried out to determine whether test microbes were killed or their growth was inhibited. Mueller Hinton and Sabouraud dextrose broths were prepared using standard procedures (Forbes et al., 2007), poured into sterilized petri dishes and allowed to cool and solidify. Content of minimum inhibition concentration in serial dilution was sub cultured onto the media; bacteria on Mueller Hinton and fungi on Sabouraud dextrose agar. Incubation was made at $37{ }^{\circ} \mathrm{C}$ for 24 hours and 30 ${ }^{0} \mathrm{C}$ for 1-7 days respectively. Thereafter, each plate was observed for colony growth. MBC/MFCs were plates with lowest concentration of extract without colony growth.

\section{RESULTS AND DISCUSSION Quantitative Phytochemistry}

Quantification of phytochemical constituents of ethyl acetate extract of Landolphia owariensis fruit pulp revealed it contained $0.03 \mathrm{mg} / 100 \mathrm{~g}$ anthraquinones, $0.12 \mathrm{mg} / 100 \mathrm{~g}$ alkaloids, 6.39 $\mathrm{mg} / 100 \mathrm{~g}$ flavonoids, $0.08 \mathrm{mg} / 100 \mathrm{~g}$ cyanogenic glycosides, $0.15 \mathrm{mg} / 100 \mathrm{~g}$ saponins, $0.55 \mathrm{mg} / 100 \mathrm{~g}$ steroids, $12.45 \mathrm{mg} / 100 \mathrm{~g}$ tannins and $0.67 \mathrm{mg} / 100 \mathrm{~g}$ triterpenes (Table 1). The high level of flavonoids in fruit pulp of L. owariensis is suggestive of its anti-oxidative properties (Okonkwo \& Osadebe, 2013; Owoyele et al., 2001; Middleton et al., 2000). Anti-oxidant property of flavonoids has been employed in protection against cancer (Lee and Shibamoto, 2002). Flavonoids have been implicated in numerous studies to have, among a host of other medicinal properties, diuretic, laxative, anti-spasmodic, anti-hypertensive, antimicrobial, anti-inflammatory and anti-radical properties (Abdelrazig, 2013; Tor-Anyiin and Anyam, 2013; Guarize et al., 2012; Nogueira and Lopes 2011; Macdonald et al., 2010; Kubmarawa and Ajoku, 2007). The high tannin content of the fruit mesocarp may confer wound healing, antibacterial properties and other numerous medicinal implications upon consumption (Liu et al., 2014; Banso and Adeyemo, 2007; Lim et al., 2006; Osadebe and Ukwueze, 2004; Tan et al., 1991). Tannins have equally been reported to act as alphaglucosidase and alpha - amylase (digestive enzymes) inhibitors thereby helping to retard postprandial blood glucose increase (Boath et al., 2012). The presence of saponins, tannins and alkaloids in the fruit pulp of L. owariensis is suggestive of anti-nutritional tendency that can cause haemolysis, nutrient malabsorption and abnormal hematopoiesis (Balogun and Akinloye, 2012). The alkaloids and saponins content of the fruit pulp however, may be employed dietetically in management of headache associated with hypertension; as well as anti-fungal agent in treatment of some fungal infections (Mensah, 2013). The cardiac glycosides levels of the mesocarp may also be used in treatment of congestive heart failure and cardiac arrhythmia (Mensah, 2013). They have also proven to be useful when used in therapeutic doses in inhibiting or preventing the growth and spread of tumors or malignant cells (Seigler, 1991; Conn, 1981; Jones, 1972).

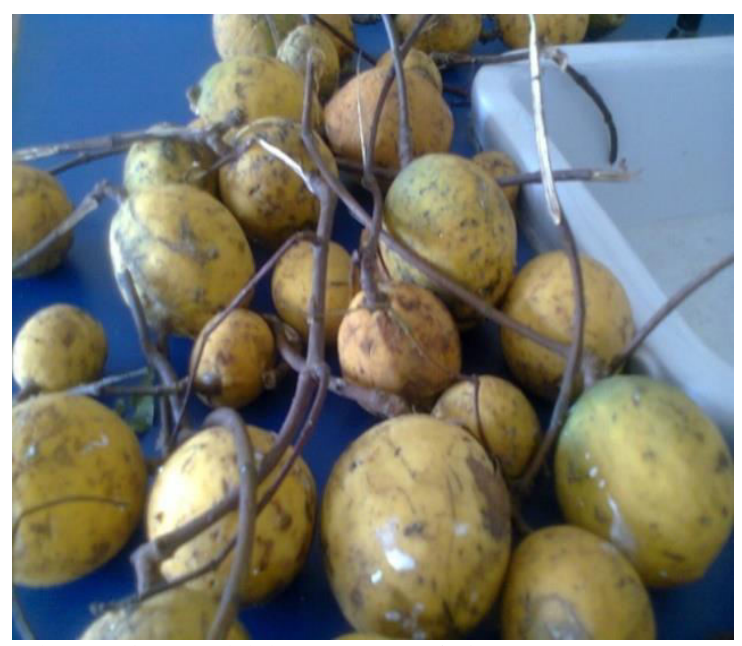

Plate 1: Ripe Landolphia owariensis fruits 
Daily intake of certain terpenoids might be useful for the management of obesity-induced metabolic disorders, such as type 2 diabetes, hyperlipidemia, insulin resistance, cardiovascular diseases, and a lower prevalence of metabolic syndrome (Goto et al., 2010). Other health benefits include reduced incidences of coronary heart disease and inflammation. Further analysis of its flavonoid composition revealed that it contained $0.02 \mathrm{mg} / \mathrm{g}$ orientin (a flavone subclass of flavonoid), 0.06 $\mathrm{mg} / \mathrm{g}$ isovitexin (a flavone subclass of flavonoid) and $0.09 \mathrm{mg} / \mathrm{g}$ kaempferol (a flavonol subclass of flavonoid). The isolation of orientin from $L$. owariensis fruit pulp is of health significance in the food industry. Lin et al. (2004) and Li et al. (2002) have demonstrated that orientin has moderate or potent antiviral activity against Para 3 virus. Apart from antiviral effects, orientin also expresses antibacterial effects. The antibacterial significance of orientin has been expressed in a study by (Ali and Dixit, 2012), in which orientin and vicenin together as flavonoids, synergistically inhibited the growth of Escherichia coli, Staphylococcus aureus, Staphylococcus cohnii, Klebsiella pneumoniae, and Proteus, while the individual flavonoids were found to be less effective than the combined flavonoids (Ali and Dixit, 2012). Similarly, orient in and vitexin in Trollius chinensis together has been reported to show evidence of antibacterial (Lin et al., 2004). Vitexin (a flavone) has been reported to lower blood pressure and exert antiinflammatory effect (Prabhakar et al., 1981), protect against cardiac hypertrophy (Lu et al., 2013), inhibit platelet aggregation (Piccinelli et al., 2008), vascular smooth contractility (Je et al., 2014) and apoptosis (Wang et al., 2015; An et al., 2015). Kaempferol a gastrointestinal lipase inhibitor hinders fat digestion and absorption (Sergent et al., 2012). Kaempferol (a flavone) also has a potent antioxidant property towards chemical induced hepatic injury (Bigoniya et al., 2013; Sahu and Gray, 1996) and has an anti-lipid peroxidative effect. The phytosterol composition of ethyl acetate extract of L. owariensis fruit pulp showed it contained $0.28 \mathrm{mg} / \mathrm{kg}, 0.81 \mathrm{mg} / \mathrm{kg}, 0.21 \mathrm{mg} / \mathrm{kg}$, $1.06 \mathrm{mg} / \mathrm{kg}, \quad 0.98 \mathrm{mg} / \mathrm{kg}$ and $0.86 \mathrm{mg} / \mathrm{kg}$ cholesterol, cholestanol, campesterol, stigmasterol, beta-sitosterol and to copherol, respectively. High intake of campesterol, sitosterol and stigmasterol has been reported to protect against obesity and atherosclerosis (Schonfeld, 2010) and decrease serum total and LDL-cholesterol levels (Izar et al., 2011). Mechanistically, phytosterols compete with cholesterol for micelle formation in the intestinal lumen and inhibit cholesterol absorption (Izar et al., 2011). Their influence on intestinal genes and transcription factors make phytosterols key regulators in metabolism and cholesterol transport in the expression of liver genes (Gupta et al., 2011, Jesch et al., 2008).

\section{Antimicrobial Activity}

Microbiological analysis of hexane, chloroform, ethyl acetate and methanol extracts of Landolphia owariensis fruit pulp showed antimicrobial activities against $S$. aureus, $S$. pyogenes, S. typhi, $S$. dysenteriae, K. pneumonia, C. albicans, C. krusei, $C$. stellatoidea and $M$. rubrum. The extracts however showed no activity on $E$. coli, $P$. aerogenosa, C. tropicalis, M. gypseum and $T$. rubrum (Table 2). The results of diameters of zones of inhibition of extracts on growth of pathogenic organisms indicate that chloroform extract had highest zones of inhibition, followed by hexane and ethyl acetate while methanol extract had least diameters of zones of inhibition. The minimum inhibition concentration (MIC) of extracts on bacterial growth showed that effect of extracts is dose dependent (Table 3). Meanwhile, extracts had minimum inhibition concentrations of $5 \mathrm{mg} / \mathrm{mL}$ (chloroform and methanol), 5 to $10 \mathrm{mg} / \mathrm{mL}$ (hexane) while ethyl acetate ranged between 2.5 $\mathrm{mg} / \mathrm{mL}$ and $5 \mathrm{mg} / \mathrm{mL}$; implying that ethyl acetate extract was more potent even at lower concentrations. The extracts ability to inhibit bacterial/fungal growth was $20 \mathrm{mg} / \mathrm{mL}$ (hexane), $10 \mathrm{mg} / \mathrm{mL}$ to $20 \mathrm{mg} / \mathrm{mL}$ (methanol and chloroform) and $5 \mathrm{mg} / \mathrm{mL}$ to $10 \mathrm{mg} / \mathrm{mL}$ (ethyl acetate). The results showed that ethyl acetate extract would be more effective in treating bacterial and fungal infections. The microbiological result of this study corroborates previous findings by Galadima et al. (2010) and Nwaogu et al. (2007) that methanolic and ethanolic extracts of leaves and roots of the plant inhibited growth of Staphylococcus aureus and Salmonella typhi, respectively. It further laid credence to the use of the leaves and roots of the plant by traditional medicine practitioners in Nigeria in treating venereal diseases.

Table 1: Phytochemical composition of Landolphia owariensis fruit pulp

\begin{tabular}{llllllll}
\hline Anthraquinones & Alkaloids & Flavonoids & Cyanogenic & Saponins & Steroids & Tannins & Terpenes \\
\hline$(\mathrm{mg} / 100 \mathrm{~g})$ & $(\mathrm{mg} / 100 \mathrm{~g})$ & $(\mathrm{mg} / 100 \mathrm{~g})$ & $\begin{array}{c}\text { glycosides } \\
(\mathrm{mg} / 100 \mathrm{~g})\end{array}$ & $(\mathrm{mg} / 100 \mathrm{~g})$ & $(\mathrm{mg} / 100 \mathrm{~g})$ & $(\mathrm{mg} / 100 \mathrm{~g})$ & $(\mathrm{mg} / 100 \mathrm{~g})$ \\
$0.03 \pm 0.02$ & $0.12 \pm 0.02$ & $6.39 \pm 2.78$ & $0.08 \pm 0.13$ & $0.15 \pm 0.03$ & $0.55 \pm 0.11$ & $12.45 \pm 0.03$ & $0.67 \pm 0.09$ \\
\hline
\end{tabular}


Table 2: Phyosterols and flavonoids composition of Landolphia owariensis fruit pulp

\begin{tabular}{|c|c|c|c|c|c|}
\hline \multicolumn{6}{|c|}{ Phytosterols } \\
\hline $\begin{array}{c}\text { Cholesterol } \\
(\mathrm{mg} / \mathrm{kg})\end{array}$ & $\begin{array}{c}\text { Cholesterol } \\
(\mathrm{mg} / \mathrm{kg})\end{array}$ & $\begin{array}{c}\text { Campesterol } \\
(\mathrm{mg} / \mathrm{kg})\end{array}$ & $\begin{array}{c}\text { Stigmasterol } \\
(\mathrm{mg} / \mathrm{kg})\end{array}$ & $\begin{array}{c}\text { Beta-sitosterol } \\
(\mathrm{mg} / \mathrm{kg})\end{array}$ & $\begin{array}{c}\text { Tocopherol } \\
(\mathrm{mg} / \mathrm{kg})\end{array}$ \\
\hline $0.28 \pm 0.01$ & $0.81 \pm 0.02$ & $0.21 \pm 0.01$ & $1.06 \pm 0.21$ & $0.98 \pm 0.01$ & $0.86 \pm 0.03$ \\
\hline \multicolumn{6}{|c|}{ Flavonoids } \\
\hline $\begin{array}{l}\text { Orientin } \\
(\mathrm{mg} / 100 \mathrm{~g})\end{array}$ & $\begin{array}{l}\text { Isoorientin } \\
(\mathrm{mg} / 100 \mathrm{~g})\end{array}$ & $\begin{array}{c}\text { Vitexin } \\
(\mathrm{mg} / 100 \mathrm{~g})\end{array}$ & $\begin{array}{l}\text { Isovitexin } \\
(\mathrm{mg} / 100 \mathrm{~g})\end{array}$ & $\begin{array}{l}\text { Quercetin } \\
(\mathrm{mg} / 100 \mathrm{~g})\end{array}$ & $\begin{array}{l}\text { Kaempferol } \\
(\mathrm{mg} / 100 \mathrm{~g})\end{array}$ \\
\hline $0.02 \pm 0.00$ & ND & ND & $0.06 \pm 0.01$ & ND & $0.09 \pm 0.14$ \\
\hline
\end{tabular}

ND - Not detected

Table 3: Anti-microbial activities and Diameter of Zone of inhibition (DZI) of Landolphia owariensis fruit pulp extracts

\begin{tabular}{|c|c|c|c|c|}
\hline \multirow[b]{2}{*}{ Microbes } & \multicolumn{4}{|c|}{ Anti-microbial activity/Zone of inhibition (mm) } \\
\hline & Hexane & Chloroform & E/Acetate & Methanol \\
\hline S. aureus & $+/ 21$ & $+/ 24$ & $+/ 20$ & $+/ 18$ \\
\hline S. pyogenes & $+/ 20$ & $+/ 23$ & $+/ 22$ & $+/ 17$ \\
\hline E. coli & $-/ 0$ & $-/ 0$ & $-/ 0$ & $-/ 0$ \\
\hline S. typhi & $+/ 23$ & $+/ 27$ & $+/ 22$ & $+/ 19$ \\
\hline S. dysenteriae & $+/ 21$ & $+/ 23$ & $+/ 21$ & $+/ 18$ \\
\hline P. aeruginosa & $-/ 0$ & $-/ 0$ & $-/ 0$ & $-/ 0$ \\
\hline K. pneumonia & $+/ 25$ & $+/ 28$ & $+/ 24$ & $+/ 19$ \\
\hline C. albicans & $+/ 23$ & $+/ 28$ & $+/ 21$ & $+/ 18$ \\
\hline C. tropicalis & $-/ 0$ & $-/ 0$ & $-/ 0$ & $-/ 0$ \\
\hline C. krusei & $+/ 24$ & $+/ 27$ & $+/ 23$ & $+/ 20$ \\
\hline C. stellatoidea & $+/ 24$ & $+/ 29$ & $+/ 22$ & $+/ 18$ \\
\hline M. gypseum & $-/ 0$ & $-/ 0$ & $-/ 0$ & $-/ 0$ \\
\hline M. spp. & $+/ 22$ & $+/ 25$ & $+/ 23$ & $+/ 18$ \\
\hline T. rubrum & $-/ 0$ & $-/ 0$ & $-/ 0$ & $-/ 0$ \\
\hline
\end{tabular}

Table 4: Minimum inhibition (MIC) and Bactericidal/Fungicidal concentrations (MBC/MFC) of Landolphia owariensis fruit pulp extracts against test microbes $(\mathrm{mg} / \mathrm{mL})$

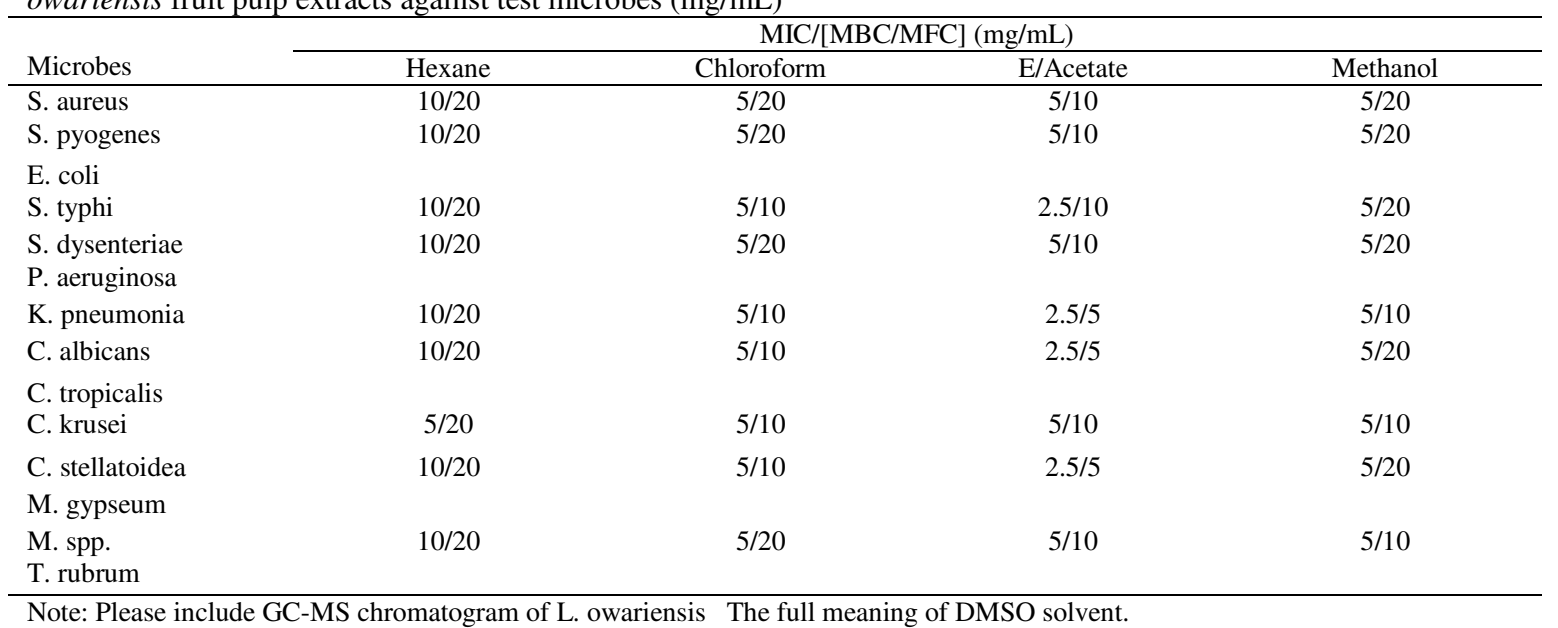

\section{CONCLUSION}

Quantification of phytochemical constituents of Landolphia oweriensis fruit pulp extracts indicated presence of important secondary metabolites. Antimicrobial studies showed that the extracts could inhibit growth of several pathogenic microorganisms (Staphylococcus aureus, Streptococcus pyogenes, salmonella typhi, Shigella dysenteriae, Klebsiella pneumonia (bacteria species), Candida albicans, Candida krusie and Candida stellatoidea (fungi species)) at even very low dosages. Incorporation of $L$. owariensis fruit flour in composite flour production for baked and porridge products may impart positively on the health status of consumers.

\section{REFERENCES}

Abdelrazig S. (2013). Isolation, characterization and biological activity of flavonoids from Vitex doniana. Asian Pacific Journal of Tropical Disease, 2 (2), 96-99

Abuin M. Carro A. and Lorenzo R. (2000). Experimental design of a microwave-assisted extractionderivatization method for the analysis of methylmercury. Journal of Chromatography Analysis, 889, 185-193

Akubugwo I.and Ugbogu A. (2007). Physicochemical studies on oils from five selected Nigerian plant seeds. Pakistan Journal of Nutrition, 6 (1), 75-78

Ali H. and Dixit S. (2012). In vitro antimicrobial activity of flavonoids of Ocimum sanctum with synergistic effect of their combined form. Asian Pacific Journal of Tropical Disease, 2 (1), S396-S398 
An F., Wang S., Tian Q. and Zhu D. (2015). Effects of orientin and vitexin from on the growth and apoptosis of esophageal cancer EC-109 cells. Oncology Letters, 10, 2627-2633

Balogun E. and Akinloye D. (2012). Biochemical effects of methanolic extract of Morinda morindoides and Morinda lucida leaves on lipid profile, bilirubin and some marker enzymes. Asian Journal of Medicinal Research, 1 (1), 12-16

Banso A. and Adeyemo S. (2007). Evaluation of antibacterial properties of tannins isolated from Dichrostachys cinerea. African Journal of Biotechnology, 6, 1785-1787

Bigoniya P., Singh C.S. and Shrivastava, B. (2013). In vivo and in vitro hepatoprotective potential of kaempferol, a flavone glycoside from capparis spinosa. International Journal of Pharmacy and Biological Sciences, 3 (4), 139-152

Boath A.S., Grussu D., Stewart D. and Mcdougall G.J. (2012). Berry polyphenols inhibit digestive enzymes: a source of potential health benefits? Food Digestion, 3 (3), 1-7

Conn E. (1981). Cyanogenic glycosides. In: P.K. Stumpf and E.E. Conn (eds.), The Biochemistry of Plants: A Comprehensive Treatise (pp. 98-101). New York: Academic Press vol. 6

Ebi G.C. and Ofoefule S.I. (1997). Investigations into the folkloric antimicrobial activities of Landolphia owriencies. Phytotherapy Research, 11 (2), 149-151

Forbes B.A., Sahm, D.F., and Weissfeld, A.S. (2007). Laboratory methods and strategies for antimicrobial susceptibility testing. In: Bailey \& Scott's Diagnostic Microbiology (pp. 187-214). St. Louis: Mosby $12^{\text {th }}$ ed

Galadima, A. Kabiru A. and Garba, Z. (2010). Phytochemical, antimicrobial and heavy metals studies of Landolphia owariensis leaves extract. International Journal of Chemistry, 20 (4), 36-40

Goto T. Takahashi N. Hirai S., and Kawada, T. (2010). Various terpenoids derived from herbal and dietary plants function as PPAR modulators and regulate carbohydrate and lipid metabolism. PPAR Research, 2010, 1-9

Guarize L. da Costa J.C. Dutra L.B. Mendes R.F. Lima I.V.A., and Scio E. (2012). Anti-inflammatory, laxative and intestinal motility effects of Senna macranthera Leaves. Natural Product Research, 26 (4), 331-343

Guinand Y. and Dechassa L. (2000). Indigenous Food Plants in Southern Ethiopia: Reflections on the role of 'famine foods' at the time of drought. United Nations Emergencies Unit for Ethiopia (UNEUE), Addis Ababa, pp. 45-47

Gupta A.K., Savopoulos C.G., Ahuja J. and Hatzitolios A.I. (2011). Role of phytosterols in lipid-lowering: current perspectives. Queen Journal of Medicine, 104 (4), 301-308

Iombor T.T. and Anyam J.V. (2015). Epicarp of the fruit of Landolphia owariensis is rich in medicinal phytochemicals and has broad spectrum antimicrobial potential. International Journal of Current Research in Chemistry and Pharmaceutical Sciences, 2 (5), 82-90

Izar M.C., Tegani D.M., Kasmas S.H. and Fonseca F.A. (2011). Phytosterols and phytosterolemia: gene-diet interactions. Genes Nutrition, 6, 17-26
Je H.G., Hong S.M., Je H.D. et al. (2014). The inhibitory effect of vitexin on the agonist-induced regulation of vascular contractility. Pharmazie, 69, 224-228

Jesch S.A., Liu P., Zhao X., Wells M.T. and Henry S.A. (2008). Multiple endoplasmic reticulum-to-nucleus signaling pathways coordinate phospholipid metabolism with gene expression by distinct mechanisms. Journal of Biology and Chemistry, 281, 24070-24083

Jones D.A. (1972). Cyanogenic glycosides and their function. In: J.B. Harborne (ed.), Phytochemical Ecology (pp. 50-53). Academic Press: London

Kebu B. and Fassil K. (2006). Ethnobotanical study of wild edible plants in Derashe and Kucha Districts. South Ethiopia. Journal of Ethnobiology and Ethnomedicine, 2, 53-58

Kubmarawa D., Ajoku G.A., Enweren N.M. and Okorie D.A. (2007). Preliminary phytochemical and antimicrobial screening of 50 medicinal plants from Nigeria. African Journal of Biotechnology, 6 (14), 1990-1996

Lee K. and Shibamoto T. (2002). Analysis of volatile components isolated from Hawaiian green coffee beans (Coffea arabica L.). Flavour and Fragrance Journal, 17, 349-351

Li Y.L., Ma S.C., Yang Y.T., Ye S.M. and But P.P.H. (2002). Antiviral activities of flavonoids and organic acid from Trollius chinensis Bunge. Journal of Ethnopharmacology, 79 (3), 365-368

Lim S.H., Darah I. and Jain K. (2006). Antimicrobial activities of tannins extracted from Rhizophora apiculata barks. Journal of Tropical Forest Science, 18 (1), 59-65

Lin Q.F., Feng S.Q., Cen Y.Z., Yang Y.T. and Wang, L.Y. (2004). Study on the antibacterial and antiviral activity compositions of Trollium chinensis Bunge," J. of Zhejiang University Science B, 31 (4), 412-415

Liu C., Zheng Y., Xu W., Wang H. and Lin N. (2014). Rhubarb Tannins Extract Inhibits the Expression of Aquaporins 2 and 3 in Magnesium SulphateInduced Diarrhoea Model. BioMedical Research International, 51 (3), 1-9

Lu C.C., Xu Y.Q., Wu J.C., Hang P.Z., Wang Y., Wang C., Wu W., Qi J.C., Zhang Y. and Du Z.M. (2013). Vitexin protects against cardiac hypertrophy via inhibiting calcineurin and CaMKII signaling pathways. Naunyn Schmiedebergs Archieve of Pharmacology, 386, 747-755

Luthria D.L., Jones A.D., Donovan J.L. and Waterhouse A.L. (1997). GC-MS determination of catechin and epicatechin levels in human plasma. Journal of High Resolution Chromatography, 20, 621-623

Macdonald I.O., Oludare A.S. and Olabiyi A. (2010). Phytotoxic and anti-microbial activities of flavonoids in Ocimum gratissimum. Life Science Journal, 7 (3), 45-48

Mensah J. (2013). Nutritional phytochemical and antimicrobial properties of two wild aromatic vegetables from Edo State. Journal of Natural products and Production Research, 3 (1), 8-14

Middleton E., Kandaswami C. and Theoharides T.C. (2000). The effects of plant flavonoids on mammalian cells: implications for inflammation, heart disease and cancer. Pharmacological Reviews, 52, 673-750

Nogueira C.R. and Lopes L.M.X. (2011). Antiplasmodial natural products. Molecules, 16 (3), 2146-2190 
Nwaogu L. Igwe C., and Emejulu A. (2008). A comparative study of the antimicrobial properties of the ethanolic extracts of Landolphia owariensis leaves and roots. African Journal of Biotechnology, 7 (4), 368-372

Nwaogu L.A., Alisi C.S., Ibegbulem C.O. and Igwe, C.U. (2007). Phytochemical and microbial activity of ethanolic extract of Landolphia owariensis leaves. African Journal of Biotechnolgy, 6 (7), 890893

Okonkwo T.J.N. and Osadebe, P.O. (2013). Isolation and characterization of potential bioactive compounds from Landolphia owariensis P. Beauv stringy seed pulp. International Journal of Applied Research in Natural Products, 6 (3), 28-38

Osadebe P.O. and Ukwueze S.E. (2004). A comparative study of the phytochemical and anti-microbial properties of the Eastern Nigerian specie of African Mistletoe (Loranthus micranthus) sourced from different host trees. Bio-Research, 2 (1), 18-23

Owoyele B.Y., Olayele S.B., and Elegba R.A. (2002). Anti-inflammatory and analgesic activities of leaf extracts of Landolphia owariensis. African Journal of Biomedical Research, 4 (3), 31-33

Piccinelli A.L., Garcia M.M., Armenteros D.M., Alfonso M.A., Arevalo A.C., Campone L. and Rastrelli L. (2008). HPLC-PDA-MS and NMR characterization of C-glycosyl flavones in a hydroalcoholic extract of Citrus aurantifolia leaves with antiplatelet activity. Journal of Agriculture and Food Chemistry, 56, 1574-1581

Prabhakar M.C., Bano H., Kumar I., Shamsi M.A. and Khan M.S. (1981). Pharmacological investigations on vitexin. Planta Medicine, 43, 396-403
Sahu S.C. and Gray G.C. (1997). Lipid peroxidation and DNA damage induced by morin and naringenin in isolated rat liver nuclei. Food and Chemical Toxicology, 35 (5), 443-447

Schonfeld G. (2010). Plant sterols in atherosclerosis prevention. American Journal of Clinical Nutrition, 92 (1), 3-4

Seigler D.S. (1991). Cyanide and cyanogenic glycosides in herbivores, their interactions with secondary plant metabolites: the chemical participants. G.A. Rosenthal and M.R. Berenbaum (eds.) Academic Press: San Diego, pp. 35-77

Sergent T., Vanderstraeten J., Winand J., Beguin P. and Schneider, Y.J. (2012). Phenolic compounds and plant extracts as potential natural anti-obesity substances. Food Chemistry, 135 (1), 68-73

Tan G.T., Pezzuto J.M., Kinghorn A.D. and Hughes, S.H. (1991). Evaluation of natural products as inhibitors of human immunodeficiency virus type 1 (HIV-1) reverse transcriptase. Journal of Natural Products, 54 (1), 143-154

Tor-Anyiin T.A. and Anyam, J.V. (2013). Phytochemical evaluation and antibacterial activity : A comparison of various extracts from some Nigerian trees. Peak Journal of Medicinal Plant Research, 1 (2), 13-18

Wang Y., Zhen Y., Wu X., Jiang Q., Li X., Chen Z., Zhang G. and Dong L. (2015). Vitexin protects brain against is chemia/reperfusion injury via modulating mitogen-activated protein kinase and apoptosis signaling in mice. Phytomedicine, 22, 379-384

Wilkes H.G. (1981). New and potential crops or what to anticipate for the future. Paper presented at the annual meeting of the American Association for the advancement of Science, January 1981. Toronto, Canada 